\title{
Effects of fungal seed pathogens under conspecific and heterospecific trees in a temperate forest
}

Post-print/Accepted manuscript

Peter M. Kotanen

Kotanen, P.M. 2007. Effects of fungal seed pathogens under conspecific and heterospecific trees in a temperate forest. Can. J. Bot. 85: 918-925 doi:10.1139/B07-088

\section{HOW TO CITE TSPACE ITEMS}

Always cite the published version, so the author(s) will receive recognition through services that track citation counts, e.g. Scopus. If you need to cite the page number of the TSpace version (original manuscript or accepted manuscript) because you cannot access the published version, then cite the TSpace version in addition to the published version using the permanent URI (handle) found on the record page. 
3 Effects of fungal seed pathogens under conspecific and heterospecific

4 trees in a temperate forest

5 Peter M. Kotanen

6

7

8

9

10

11 Peter M. Kotanen

12 Department of Ecology and Evolutionary Biology

13 University of Toronto at Mississauga

143359 Mississauga Road North

15 Mississauga, Ontario, L5L 1C6 CANADA

16 Phone: 905-828-5365

17 FAX: 905-828-3792

18 e-mail: pkotanen@utm.utoronto.ca

19 
Contrasting effects of seed pathogens...

20 Abstract: This study investigated the impacts of soil fungi on seeds of two eastern North

21 American temperate-zone trees: Acer saccharum (sugar maple) and Tsuga canadensis (eastern

22 hemlock). Seeds of each species were buried at locations dominated by either conspecifics or

23 heterospecifics. Half were protected with fungicide, and net consequences for survival and

24 germination were assessed. Net effects of fungicide usually were positive, indicating pathogens

25 affected seeds more strongly than any potential mutualists. Losses of A. saccharum to fungi were

26 modest, and almost identical in areas dominated by itself vs. areas dominated by T. canadensis. In

27 contrast, fungal impacts on T. canadensis were strongly habitat-dependent: losses to fungi were

28 high in T. canadensis-dominated sites, but not in A. saccharum-dominated sites. This result is

29 consistent with an accumulation of host-specific pathogens, either by a direct feedback between

30 T. canadensis and its fungal enemies, or indirectly through modification of the soil environment.

31 Even though these two trees share similar habitats, responses to fungicide indicate that their seeds

32 are affected very differently by the soil environment.

34 Key words: Acer saccharum, fungi, pathogens, seed bank, Tsuga canadensis, seeds 
Contrasting effects of seed pathogens...

\section{Introduction}

Pathogens can have important impacts on plant populations and communities (Dobson and Crawley 1994; Gilbert 2002; Van der Putten 2003). For example, soil fungi have been demonstrated to reduce tree seed and seedling survival and growth in a variety of temperate (e.g.,

40 Stanosz 1993; Zhong and van der Kamp 1999; Packer and Clay 2000, 2003; Masaki and

41 Nakashizuka 2002; Tomita et al. 2002) and tropical (e.g., Augspurger 1983; Kitajima and

42 Augspurger 1989; Forget 1997; Dalling et al. 1998) forest systems. These impacts often are

43 spatially variable: mortality may be higher in sites with large fungal populations, and lower in

44 sites favoring trees' growth and defense (Augspurger 1984; Augspurger and Kelly 1984; Forget

45 1997; Zhong and van der Kamp 1999; DeWalt et al. 2004; O'Hanlon-Manners and Kotanen

46 2004a). As an example, white birch (Betula papyrifera Marsh.) experiences lower losses of seeds

47 to fungi in fields than in forests, suggesting pathogens may contribute to the dependence of this

48 species on open sites for recruitment (O'Hanlon-Manners and Kotanen 2004b).

Spatial variation in populations of pathogens often can be linked to variation in the

50 physical or biotic environment. For example, wetter soils may sustain larger populations of

51 harmful fungi (Blaney and Kotanen 2001; Schafer and Kotanen 2003). Consequently, treefall

52 gaps or other relatively dry openings may provide a refuge from pathogens prevalent in the moist,

53 shady understory (Augspurger 1984; Augspurger and Kelly 1984; Forget 1997; Wenny and Levey

54 1998; O'Hanlon-Manners and Kotanen 2004b). As another example, fungi may be more abundant

55 in soils with greater organic content or a higher C: N ratio (Wardle 2002); this also might increase

56 the risk of attack (Zhong and van der Kamp 1999). Plants themselves may affect pathogen

57 populations by a variety of direct and indirect mechanisms. Indirect mechanisms may involve

58 plants modifying soil C: $\mathrm{N}$ ratio or chemistry via the input of organic material, or modifying soil

59 moisture by changing evapotranspiration rates (Wardle 2002; Van der Putten 2003). These soil 
Contrasting effects of seed pathogens...

60 changes can affect pathogen populations as described above. The best-studied direct mechanism

61 is soil microbial feedback: the buildup of pathogen populations in response to the presence of

62 host species (Van der Putten et al. 1993; Bever 1994; Bever et al. 1997; Mills and Bever 1998;

63 Van der Putten 2003). This may render recruitment more difficult in areas dominated by

64 conspecific adults, as originally suggested by Janzen (1970) and Connell (1971) (the "Janzen-

65 Connell Hypothesis"). Studies providing evidence of density- or distance- dependent recruitment

66 suggest this model may be widely applicable in tropical forests (Clark and Clark 1984; Wills et

67 al. 1997; Harms et al. 2000; Wright 2002; but see Hyatt et al. 2003 for a strong contrary view).

68 Evidence from temperate regions is more limited, but suggests density-dependent predators and

69 pathogens may similarly affect recruitment in forests (Packer and Clay 2000; Hille Ris Lambers

70 et al. 2002). Soil feedback is not always negative: some species may cultivate mycorrhizae or

71 other soil microflora that improve their own performance or reduce that of their competitors

72 (Klironomos 2003; Callaway et al. 2004a, b; Hood et al. 2004; Weber et al. 2005).

I designed this study to experimentally investigate the impacts of fungal pathogens

74 (including true pathogens, seed decay fungi, and other antagonists) on seeds of two co-occurring

75 temperate forest trees: Acer saccharum Marsh. (sugar maple) and Tsuga canadensis (L.) Carr

76 (eastern hemlock). These species alter soil conditions in distinctly different ways (Pastor et al.

77 1984; Mladenoff 1987; Frelich et al. 1993; Finzi et al. 1998a, b), with consequences for their

78 recruitment. There is evidence that surface soil characteristics such as low $\mathrm{pH}$, high soil carbon,

79 and low nitrogen availability reduce recruitment by $A$. saccharum in $T$. canadensis-dominated

80 areas, while a thick, dry layer of leaf litter inhibits recruitment of T. canadensis in A. saccharum-

81 dominated sites (Frelich et al. 1993; Catovsky and Bazzaz 2000). These mutually negative

82 interactions may explain why these two species tend to be negatively associated on a local (stand)

83 scale (Frelich et al. 1993). However, it is possible that interactions with the soil microbial 
Contrasting effects of seed pathogens...

84 community might significantly modify these effects. In principle, microbes might respond to soil

85 changes such that each tree species cultivates a pathogen community hostile to the other, further

86 reducing heterospecific recruitment. Alternatively, soil changes and/or the accumulation of

87 species-specific pathogens predicted by the Janzen-Connell Hypothesis might favour microbial

88 communities that cause each species to inhibit its own recruitment, though evidently not enough

89 to eliminate the observed pattern of stand dominance. Thus, soil microbes might tend either to

90 reinforce or to reduce stand stability.

91 My experiment tested the hypothesis that the net effect of soil fungi on seeds of each of

92 my study species is more negative at sites where that tree is common vs. sites where it is scarce.

93 To accomplish this, I used fungicide to treat seeds in habitats dominated by both conspecifics and

94 heterospecifics, with untreated controls. Comparison of fungicide-treated seeds vs. untreated

95 seeds allowed me to estimate of the net effect of the soil fungal community: improved survival of

96 fungicide-treated seeds indicates that the effects of pathogens outweighed the effects of any

97 beneficial species. My results demonstrate that seeds of these two co-occurring tree species

98 responded very differently to fungicide applications, suggesting that seed pathogens may play a

99 different role in each case.

100 Materials and Methods

101 Study site

102 This experiment was conducted at the University of Toronto's Koffler Scientific Reserve

103 at Jokers Hill, Regional Municipality of York, in southern Ontario, Canada $\left(44^{\circ} 02^{\prime} \mathrm{N}, 7^{\circ} 31^{\prime} \mathrm{W}\right.$,

104 300m elevation). This 350-ha site lies within the Oak Ridges Moraine, and is characterized by

105 prominent hills with a thin organic layer over deep glacial sands. Experimental plots were

106 established throughout a single large $\left(>1 \mathrm{~km}^{2}\right)$ tract of mature forest near the centre of this

107 property. The most abundant tree in this tract is $A$. saccharum, but $T$. canadensis occurs patchily 
Contrasting effects of seed pathogens...

108 throughout, generally in stands < 1ha in area. Other species typical of the temperate Great Lakes

109 Forest region also are present, notably including American beech (Fagus grandifolia Ehrh.),

110 yellow birch (Betula alleghaniensis Britton), and eastern white pine (Pinus strobus L.). Further

111 information on this site may be found at http://www.zoo.utoronto.ca/jokershill/jh.html.

112 Experimental species

113 Acer saccharum is the dominant mature forest tree throughout much of southeastern

114 Canada and the northeastern USA (Godman et al. 1990; Farrar 1995). This deciduous species is

115 very shade-tolerant, and can persist for decades as small saplings in deep shade in the forest

116 understory until a canopy gap opens (Godman et al. 1990; Farrar 1995). The winged seeds are

117 dispersed from October to December (Schopmeyer 1974). These seeds do not persist long in the

118 soil (Marquis 1975; Houle 1994), but germinate very early in spring, often while snow is still

119 present (Godman et al. 1990, Farrar 1995). A. saccharum seeds seem relatively resistant to fungal

120 attack: O'Hanlon-Manners and Kotanen (2006) did not detect a significant improvement in seed

121 survival in response to protection with fungicide.

122 Tsuga canadensis is a highly shade-tolerant, late-successional conifer, and co-occurs with

123 A. saccharum throughout much of eastern North America (Anderson and Gordon 1994). The

124 winged seeds are wind-dispersed during fall and winter (Fowells 1965; Godman and Lancaster

125 1990), and germinate in June or July in northern areas (Fowells 1965). T. canadensis does not

126 form a persistent seed bank (Marquis 1975; Hille Ris Lambers et al. 2005). Saplings frequently

127 recruit on decaying logs and stumps (Godman and Lancaster 1990, Anderson and Gordon 1994),

128 in part because seedlings are prone to smothering by leaf litter on the forest floor (Anderson and

129 Gordon 1994), but also because these microhabitats provide a refuge from pathogenic fungi that

130 reduce viability of seeds buried in soil (O'Hanlon-Manners and Kotanen 2004a). 
Contrasting effects of seed pathogens...

131

132

133

134

135

136

137

138

139

140

141

142

143

144

145

146

147

148

149

150

151

152

153

154

\section{Experimental methods}

Sixteen experimental plots were established in June 2002, scattered throughout mature maple-beech-hemlock forest; eight were located in eight different T. canadensis-dominated sites, and the remaining plots in eight $A$. saccharum-dominated sites. Sites were tens to hundreds of meters apart, and contained numerous large trees of the focal species. At each site, approximately $20 \mathrm{~mL}$ of fresh local soil was used to fill four seed bags, each made from a knee-high nylon stocking; this soil was collected from just below the surface organic layer, and was nearly pure sand. Fifteen seeds, provided from Ontario sources by the National Tree Seed Centre (Natural Resources Canada, Canadian Forest Service, Fredericton, New Brunswick), were added to each bag: seeds of $T$. canadensis to two bags per site, and seeds of A. saccharum to the other two. Although this is a modest sample size, it is not unreasonably small: a total of 960 seeds was used in this experiment (480 per species), and the demonstration of statistically significant results (see below) shows that this provided sufficient power for the detection of important treatment effects. This experiment was designed to compare the net effects of the entire fungal community on buried seeds subjected to different treatments, rather than to estimate absolute levels of mortality or to isolate the effects of specific pathogens. One bag of each species was saturated with a broad-spectrum fungicide (1:100 solution of Maestro 75DF in water: Zeneca Corp., Ontario, Canada); the other was saturated with water as a control. The active ingredient in this fungicide (75\% by weight) is Captan (3a,4,7,7a-tetrahydro-2-[(trichloromethyl)thio]-1Hisoindole-1,3(2H)-dione), a nonsystemic heterocyclic nitrogen fungicide effective against a broad range of Oomycota, Ascomycota and Basidiomycota (Sharvelle 1961; Torgeson 1969; Neergaard 1977); my lab has successfully used Captan in a series of similar experiments (Blaney and Kotanen 2001, 2002; Schafer and Kotanen 2003; O'Hanlon-Manners and Kotanen 2004a,b). It is expected that short-lived seeds should be concentrated near the soil surface (Baskin and Baskin 
Contrasting effects of seed pathogens...

155 1998); thus, seed bags were buried as shallowly as practically possible $(5-10 \mathrm{~cm})$ in the surface

156 soil layer, separated from one another by approximately $1 \mathrm{~m}$. Fungicide and water treatments were

157 re-applied at approximately monthly intervals by saturating the immediate site of burial of each

158 bag; bags were far enough apart that significant cross-contamination seems unlikely. Use of seed

159 bags may underestimate survival in natural soils (Van Mourik et al. 2005); however, this should

160 not bias comparisons between experimental treatments.

161 These bags were retrieved in November 2002 and returned to the laboratory, where seeds

162 were recovered by sieving. Bags that were not recovered intact were excluded from analyses, as

163 were any missing seeds. Field-germinated seeds were counted and removed, and the remaining

164 seeds were transferred to germination treatments based on information provided by the National

165 Tree Seed Centre, and shown to maximize germination in previous experiments (O'Hanlon-

166 Manners and Kotanen 2006). T. canadensis seeds were placed in pots filled with potting soil, and

167 initially placed in a germination chamber $\left(12 \mathrm{~h} / 12 \mathrm{~h}, 5^{\circ} \mathrm{C} / 25^{\circ} \mathrm{C}\right.$, light/dark cycle; $90 \%$ humidity);

168 in December, these pots were moved to a greenhouse. A. saccharum seeds, which germinate best

169 at low temperatures (Godman et al. 1990; Farrar 1995), were placed in plastic ziplock bags in a

170 dark refrigerator (approximately 5C). These seeds were kept wet at all times. Seeds of both

171 species were examined at monthly intervals until March (4 months), and classified as

172 "germinated", "intact" (firm and apparently undiseased), or "dead" (soft or rotten); the distinction

173 between these categories generally was very obvious. Germinated and dead seeds were then

174 removed. Seeds were classed as "surviving" if they germinated in either the field or the lab, or if

175 they still remained intact by the end of the experiment.

176 Statistical analyses

177 Statistical analyses were performed using the EMS "Fit Model" routine of JMP 5 (2002,

178 SAS Institute Inc., Cary, NC). Results for A. saccharum and T. canadensis were analyzed 
Contrasting effects of seed pathogens...

179 separately, since these species exhibited different responses; because these two analyses were

180 based on seeds sharing the same plots, they are not fully independent. The proportion of

181 recovered seeds that survived was analyzed with split-plot factorial ANOVAs (with site treated as

182 a random block), following an arcsin-squareroot transformation (Kirk 1995). This is a more

183 appropriate analysis than methods treating the fate of each seed as a binomial variable (e.g.,

184 logistic analyses) because it does not assume that the seeds within each bag are independent. The

185 focus of this experiment was on responses to treatments rather than estimation of absolute levels

186 of mortality. For instance, comparison of fungicide additions vs. controls allows estimation of the

187 net effect of the soil fungal community, including both harmful and beneficial species. Increased

188 survival in response to fungicide addition therefore indicates that the influence of pathogens on

189 survival exceeded that of mutualists, such as mycorrhizal fungi; the larger this increase, the more

190 negative the net effect of the fungal community. Since some seeds germinated in the field,

191 pathogens may include both seed pathogens and early seedling pathogens. It was expected that the

192 positive influence of mycorrhizal species would be relatively small, since these primarily affect

193 growth following root development, and thus are unlikely to strongly affect seed survival and

194 germination. Means are reported \pm one standard error.

195 Results

196 Of the 64 experimental bags, 58 were recovered intact. These bags should have contained

197870 seeds. The fate of 843 of these seeds (417 A. saccharum and 426 T. canadensis) could be

198 determined; the remaining 3 A. saccharum and 24 T. canadensis seeds were not located or were

199 lost during processing, and were excluded from analyses. Of these 843 seeds, 123 germinated in

200 the field (all T. canadensis), while 244 A. saccharum seeds germinated in the lab vs. 77 seeds of

201 T. canadensis. Only 10 A. saccharum seeds and 0 (zero) T. canadensis seeds remained

202 ungerminated but apparently intact at the end of the experiment; thus, misclassification of intact 
Contrasting effects of seed pathogens...

203 but dead seeds as living is unlikely to have strongly biased estimates of survival. Overall, 61\% of

204 A. saccharum seeds and $47 \%$ of $T$. canadensis seeds were judged to have survived the experiment

205 (as germinated or intact); most of the remainder were obviously decayed, often with visible

206 colonies of fungi or bacteria.

207 Analyses of overall survival (i.e., germinated seeds plus intact seeds) indicated that $A$.

208 saccharum and T. canadensis responded to fungal pathogens in strongly contrasting ways (Table

209 1; Fig. 1). A. saccharum showed a marginally significant $(\mathrm{p}=0.07)$ improvement in survival in

210 response to fungicide (Table 1); however, this response was very similar (a 13\%-14\% increase) in

211 both $A$. saccharum-dominated sites (control: $57 \pm 6 \%$; fungicide: $70 \pm 6 \%$ ) and T. canadensis-

212 dominated sites (control: $51 \pm 8 \%$; fungicide: $65 \pm 4 \%$ ) (Fig. 1a), leading to a nonsignificant

213 habitat effect and habitat $\mathrm{x}$ treatment interaction. In contrast, T. canadensis responded differently

214 to fungicide in each habitat (Fig. 1b), leading to a significant habitat $\mathrm{x}$ treatment interaction

215 (Table 1). In T. canadensis-dominated sites, fungicide improved seed survival from 38\% \pm 5\% to

$21663 \% \pm 7 \%$ : a 25\% increase; in A. saccharum-dominated sites, survival was nearly unaffected,

217 changing from $47 \% \pm 10 \%$ to $44 \% \pm 6 \%$ : a 3\% decrease. Excluding seeds that failed to germinate

218 did not alter patterns of significance for either species.

\section{Discussion}

Previous research at this location has documented significant impacts of soil fungi on seeds in a variety of forest (O'Hanlon-Manners and Kotanen 2004a,b, 2006) and non-forest

222 (Blaney and Kotanen 2001, 2002; Schafer and Kotanen 2003) systems. The present study again

223 demonstrates that soil fungal pathogens have the potential to affect the early stages of

224 recruitment, likely including both seeds and germinating seedlings (e.g., Packer and Clay 2000).

225 Although in principle the fungicide used might affect mutualists such as mycorrhizae, its net

226 effects usually were positive, indicating that (as expected) pathogens affected seeds of both $A$. 
Contrasting effects of seed pathogens...

227 saccharum and T. canadensis more strongly than any potential mutualists. The improvement for

228 A. saccharum was relatively modest, and was significant only at the $\mathrm{p}=0.07$ level (likely because

229 of limited statistical power). The improvement for $T$. canadensis was much more substantial, at

230 least in conspecific-dominated sites: a 1.6-fold increase, suggesting greater susceptibility to

231 fungal attack. Since this study was performed from summer to fall, while non-dormant seeds

232 primarily occur in soil from winter to spring, there is a risk that the microbial communities

233 experienced by seeds in this experiment differed from those naturally encountered (e.g., Lipson et

234 al. 2002). However, over-winter studies previously conducted with the same species at the same

235 site (O'Hanlon-Manners and Kotanen 2004a, 2006) also have found significant losses to seed

236 fungi in $T$. canadensis, but not A. saccharum, suggesting patterns of mortality are similar. This

237 study adds to accumulating evidence that pathogens present in the soil may play a significant (but

238 underappreciated) role in reducing establishment success in both temperate and tropical forests.

239 The principal goal of the field experiment reported in this paper was to compare the

240 impacts of seed-attacking fungi between sites where each tree species is common vs. sites where

241 it is scarce. These impacts differed markedly between the two study species. Losses of seeds of $T$.

242 canadensis were strongly habitat-dependent: losses were high in T. canadensis-dominated sites,

243 but not in A. saccharum-dominated sites. One possible explanation for this pattern may be that

244 feedback between T. canadensis and the soil biota directly enhances populations of host-specific

245 pathogens, as has for instance been shown for black cherry (Prunus serotina Ehrh.) (Packer and

246 Clay 2000, 2003; Reinhart et al. 2003, 2005). A second possibility may be that T. canadensis

247 modifies the physical environment around itself in such a way as to indirectly increase pathogen

248 populations. For example, soils beneath T. canadensis tends to become enriched in carbon, while

249 the rapid decomposition of $A$. saccharum leaf litter leads to lower soil organic content (Pastor et

250 al. 1984; Frelich et al. 1993; Finzi et al. 1998b): more soil carbon may favor larger fungal 
Contrasting effects of seed pathogens...

251 populations (Wardle 2002). Knowing the identity of the pathogens involved might distinguish

252 between these two possibilities: are they obligately host-specific, or facultatively pathogenic

253 saprobes? Interestingly, when treated with fungicide, seeds of T. canadensis tended to perform

254 better under conspecifics than heterospecifics, perhaps suggesting a positive effect of local soil

255 composition or associated non-fungal biota.

256 A. saccharum exhibited very different patterns of seed survival. Although fungi tended to

257 reduce seed viability, estimates of losses to fungi were almost identical in areas dominated by $A$.

258 saccharum vs. areas dominated by T. canadensis, suggesting changes in fungal populations were

259 not more strongly reducing survival in A. saccharum-dominated sites. This absence of a habitat $\mathrm{x}$

260 fungicide treatment interaction also suggests that while soil changes beneath $T$. canadensis may

261 inhibit recruitment of A. saccharum (Frelich et al. 1993; Catovsky and Bazzaz 2000), the

262 mechanism does not involve seed-attacking fungal pathogens, although it is always possible that

263 pathogens may have stronger effects on later life history stages. One possible explanation for the

264 consistency of fungal attack in A. saccharum may be that seed mortality was caused by generalists

265 or unspecialized seed-decay fungi rather than host-specific pathogens. Alternatively, seeds may

266 have been lost to specialist pathogens that are ubiquitous within maple-dominated landscapes,

267 including embedded stands of T. canadensis. Reinhart and Callaway (2004) similarly reported

268 that the effects of soil biota on seedlings of Acer negundo L. and Acer platanoides L. in their

269 respective native regions were equally negative under both conspecifics and heterospecifics,

270 despite evidence of both specialist and generalist pathogens.

271 Results of this study suggest that interactions involving seed pathogens do not reduce the

272 stability of $A$. saccharum stands. In contrast, they do seem to indicate that $T$. canadensis might

273 have trouble recruiting in areas dominated by conspecifics. Despite this, studies elsewhere have

274 found evidence that mature $T$. canadensis has positive or neutral effects on populations of its own 
Contrasting effects of seed pathogens...

275 saplings (Frelich et al. 1993; Catovsky and Bazzaz 2000, 2002), and established stands can persist

276 for thousands of years (Foster and Zebryk 1993; Davis et al. 1998). Assuming these studies are

277 representative, a potential explanation for this discrepancy may be that other factors outweigh any

278 disadvantage resulting from seed pathogens accumulating near conspecifics. For example,

279 dispersal limitation may be more important than other constraints on establishment (e.g., Hubbell

280 et al. 1999): the heavy seed rain in established hemlock stands (Catovsky and Bazzaz 2000) may

281 be great enough to outweigh any negative features of such sites. Hemlock stands may provide

282 refuge from the deep leaf layer annually deposited by deciduous trees, and thus improve seedling

283 establishment (Frelich et al. 1993). T. canadensis saplings may benefit because the deep shade

284 beneath adults excludes most competitors from hemlock stands (Catovsky and Bazzaz 2000,

285 2002). Finally, the benefits provided by host-specific mutualists, such as mycorrhizae, may

286 counteract the risks of host-specific disease. Maples are AM-mycorrhizal, while hemlocks instead

287 rely on ectomycorrhizae; thus, positive feedbacks in sites dominated by the appropriate

288 mycorrhizae might eventually outweigh negative interactions during seed dormancy and

289 germination (e.g., Weber et al. 2005). Increased risk of seed mortality in T. canadensis stands

290 may reduce the extent of such benefits, and thus the stability of established stands, but evidently

291 not sufficiently to disrupt them.

292 One other possibility is that the ability of T. canadensis to establish on logs may help to

293 buffer it against the impacts of soil fungi: logs may increase survival of seedlings by initially

294 providing low-pathogen microsites (O'Hanlon-Manners and Kotanen 2004a). A. saccharum,

295 which generally recruits on the forest floor, may reduce pathogen attack with a different strategy.

296 A. saccharum may evade pathogens by germinating very early in the year, so that seedlings will

297 be larger, tougher, thicker-barked, and therefore less vulnerable by the time warmer temperatures

298 encourage the growth of many pathogens (see Seiwa 1998 for evidence from Acer mono 
Contrasting effects of seed pathogens...

299 Maxim.). Following germination, A. saccharum seedlings persist in a juvenile state for years or

300 decades (Marks and Gardescu 1998; Godman et al. 1990); it may be that this metabolically active

301 "seedling bank" is safer from pathogens than seeds exposed for long periods in a seed bank.

302 In summary, buried seeds of T. canadensis and A. saccharum responded differently to

303 protection with fungicide: benefit for T. canadensis was markedly greater near conspecifics,

304 while benefit for A. saccharum was smaller and spatially more homogeneous. These differing

305 responses likely are related to interactions between these trees and both physical and biotic

306 characteristics of the soil. Thus, even though these two shade-tolerant, mature forest trees occur

307 in the same habitats, their seeds respond very differently to this shared environment.

\section{Acknowledgements}

309 This research was supported by NSERC Research and Equipment Grants. Stephanie

310 deLorenzo, Lesley Cresswell, and Gord McNickle provided field and lab assistance. The National

311 Tree Seed Centre kindly donated the seeds used in this experiment. This research complied with

312 all local laws. This is a publication of the Koffler Scientific Reserve at Jokers Hill. 
Contrasting effects of seed pathogens...

\section{References}

Anderson, H.W., and Gordon, A.G. 1994. Hemlock: its ecology and management. In The tolerant conifers: eastern hemlock and red spruce, their ecology and management. Edited by H.W.

Anderson. Ontario Forest Research Institute, Sault Ste. Marie, Ontario pp. 62-114.

Augspurger, C. 1983. Seed dispersal of the tropical tree, Platypodium elegans, and the escape of its seedlings from fungal pathogens. J. Ecol. 71: 759-771.

Augspurger, C. 1984. Seedling survival of tropical tree species: interactions of dispersal distance, light-gaps, and pathogens. Ecology, 65: 1705-1712.

Augspurger, C., and Kelly, C.K. 1984. Pathogen mortality of tropical tree seedlings: experimental studies of the effects of dispersal distance, seedling density, and light conditions. Oecologia, 61: 211-217.

Baskin, C.C. and Baskin, J.M. 1998. Seeds: Ecology, Biogeography, and Evolution of Dormancy and Germination. Academic Press, San Diego.

Bever, J.D. 1994. Feedback between plants and their soil communities in an old field community. Ecology, 75: 1965-1977.

Bever, J.D., Westover, K.M., and Antonovics, J. 1997. Incorporating the soil community into plant population dynamics: the utility of the feedback approach. J. Ecol. 85: 561-573.

Blaney, C.S., and Kotanen, P.M. 2001. Effects of fungal pathogens on seeds of native and exotic plants: a test using congeneric pairs. J. Appl. Ecol. 38: 1104-1113.

Blaney, C.S., and Kotanen, P.M. 2002. Persistence in the seed bank: an experimental comparison of native and alien plants. Écoscience, 9: 509-517.

Callaway, R.M., Thelen, G.C., Barth, S., Ramsey, and P.W., Gannon, J.E. 2004a. Soil fungi alter interactions between the invader Centaurea maculosa and North American natives. Ecology, 85: 1062-1071. 
Contrasting effects of seed pathogens...

Callaway, R.M., Thelen, G.C., Rodriguez, A., and Holben, W.E. 2004b. Soil biota and exotic plant invasion. Nature, 427: 731-733.

Catovsky, S., and Bazzaz, F.A. 2000. The role of resource interactions and seedling regeneration in maintaining a positive feedback in hemlock stands. J. Ecol. 88: 100-112.

Catovsky, S., and Bazzaz, F.A. 2002. Feedbacks between canopy composition and seedling regeneration in mixed conifer broad-leaved forests. Oikos, 98: 403-420.

Clark, D.A., and Clark, D.B. 1984. Spacing dynamics of a tropical rain forest tree: evaluation of the Janzen-Connell model. Am. Nat. 124: 769-788.

Connell, J.H. 1971. On the role of natural enemies in preventing competitive exclusion in some marine animals and in rain forests. In Dynamics of populations. Edited by P.J. Den Boer and G. Gradwell. Advanced Study Institute on Dynamics of Numbers in Populations, Wageningen, the Netherlands, pp. 298-312.

Dalling, J.W., Swaine, M.D., and Garwood, N.C. 1998. Dispersal patterns and seed bank dynamics of pioneer trees in moist tropical forest. Ecology, 79: 564-578.

Davis, M.B., Calcote, R.R., Sugita, S., and Takahara, H. 1998. Patchy invasion and the origin of a hemlock-hardwoods forest mosaic. Ecology, 79: 2641-2659.

DeWalt, S.J., Denslow, J.S., and Ickes, K. 2004. Natural-enemy release facilitates habitat expansion of the invasive tropical shrub Clidemia hirta. Ecology, 85: 471-483.

Dobson, A., and Crawley, M. 1994. Pathogens and the structure of plant communities. Trends Ecol. Evol. 9: 393-398.

Farrar, J.L. 1995. Trees in Canada. Fitzhenry and Whiteside Ltd, Ottawa.

Finzi, A.C., Canham, C.D., and Van Breemen, N. 1998a. Canopy tree-soil interactions within temperate forests: species effects on pH and cations. Ecol. Appl. 8: 447-454. 
Finzi, A.C., Van Breemen, N., and Canham, C.D. 1998b. Canopy tree-soil interactions within temperate forests: species effects on soil carbon and nitrogen. Ecol. Appl. 8: 440-446.

Forget, P.M. 1997. Effect of microhabitat on seed fate and seedling performance in two rodentdispersed tree species in rain forest in French Guiana. J. Ecol. 85: 693-703.

Foster, D.R., and Zebryk, T.M. 1993. Long-term vegetation dynamics and disturbance history of a Tsuga-dominated forest in New England. Ecology, 74: 982-998.

Fowells, H.A. 1965. Eastern hemlock (Tsuga canadensis (L.) Carr.). In Silvics of forest trees of the United States. Edited by H.A. Fowell. USDA Forest Service, Washington, DC pp. 703711.

Frelich, L.E., Calcote, R.R., and Davis, M.B. 1993. Patch formation and maintenance in an oldgrowth hemlock-hardwood forest. Ecology, 74: 513-527.

Gilbert, G.S. 2002. Evolutionary ecology of plant diseases in natural ecosystems. Annu. Rev. Phytopath. 40: 13-43.

Godman, R.M., and Lancaster, K. 1990. Tsuga canadensis (L.) Carr. eastern hemlock. In silvics of North America, volume 1: conifers. Edited by R.M. Burns and B.H. Honkala. USDA Forest Service, Washington, D.C. pp. 604-612.

Godman, R.M., Yawney, H.W., and Tubbs, C.H. 1990. Acer saccharum Marsh. sugar maple. In Silvics of North America, volume 2: hardwoods. Edited by R.M. Burns and B.H. Honkala. USDA Forest Service, Washington, D.C. pp. 78-90.

Harms, K.E., Wright, S.J., Calderon, O., Hernandez, A., and Herre, E.A. 2000. Pervasive densitydependent recruitment enhances seedling diversity in tropical forest. Nature, 404: 493-495.

Hille Ris Lambers, J., Clark, J.S., and Beckage, B. 2002. Density-dependent mortality and the latitudinal gradient in species diversity. Nature, 417: 732-735.

Hood, L.A., Swaine, M.D., and Mason, P.A. 2004. The influence of spatial patterns of damping- 
Contrasting effects of seed pathogens...

off disease and arbuscular mycorrhizal colonization on tree seedling establishment in Ghanian tropical forest soil. J. Ecol. 92: 816-823.

Houle, G. 1994. Spatiotemporal patterns in the components of regeneration of four sympatric tree species - Acer rubrum, A. saccharum, Betula alleghaniensis and Fagus grandifolia. J. Ecol. 82: 39-53.

Hubbell, S.P., Foster, R.B., O’Brien, S.T., Harms, K.E., Condit, R., Wechsler, B., Wright, S.J., and Loo de Lao, S. 1999. Light-gap disturbances, recruitment limitation, and tree diversity in a neotropical forest. Science, 283: 554-557.

Hyatt, L.A., Rosenberg, M.S., Howard, T.G., Bole, G., Fang, W., Anastasia, J., Brown, K., Grella, R., Hinman, K., Kurdziel, J.P., and Gurevich, J. 2003. The distance dependence prediction of the Janzen-Connell hypothesis: a meta-analysis. Oikos, 103: 590-602.

Janzen, D.H. 1970. Herbivores and the number of tree species in tropical forests. Am. Nat. 104: 501-528.

Kirk, R.E. 1995. Experimental design: procedures for the behavioral sciences, 3rd edn. Brooks/Cole, Pacific Grove.

Kitajima, K., and Augspurger, C.K. 1989. Seed and seedling ecology of a monocarpic tropical tree, Tachigalia versicolor. Ecology, 70: 1102-1114.

Klironomos, J. 2003. Variation in plant response to native and exotic arbuscular mycorrhizal fungi. Ecology, 84: 2292-2301.

Lipson, D.A., Schadt, C.W., and Schmidt, S.K. 2002. Changes in soil microbial community structure and function in an alpine dry meadow following spring snow melt. Microbial Ecol. 43: 307-314.

Marquis, D.A. 1975. Seed storage and germination under northern hardwood forests. Can. J. For. Res. 5: 478-484. 
Marks, P.L., and Gardescu, S. 1998. A case study of sugar maple (Acer saccharum) as a forest seedling bank species. J. Torrey Bot. Soc. 125: 287-296.

Masaki, T., and Nakashizuka, T. 2002. Seedling demography of Swida controversa: effect of light and distance to conspecifics. Ecology, 83: 3497-3507.

Mills, K.E., and Bever, J.D. 1998. Maintenance of diversity within plant communities: soil pathogens as agents of negative feedback. Ecology, 79: 1595-1601.

Mladenoff, D.J. 1987. Dynamics of nitrogen mineralization and nitrification in hemlock and hardwood treefall gaps. Ecology, 68: 1171-1180.

Neergaard, P. 1977. Seed pathology, volume 1. Halsted Press, New York.

O'Hanlon-Manners, D.L., and Kotanen, P.M. 2004a. Logs as refuges from fungal pathogens for seeds of Eastern Hemlock (Tsuga canadensis). Ecology, 85: 284-289.

O'Hanlon-Manners, D.L., and Kotanen, P.M. 2004b. Evidence that fungal pathogens inhibit recruitment of a shade-intolerant tree, White Birch (Betula papyrifera), in understory habitats. Oecologia, 140: 650-653.

O'Hanlon-Manners, D.L., and Kotanen, P.M. 2006. Losses of seeds of temperate trees to soil fungi: effects of habitat and host ecology. Plant Ecol. 187: 49-58.

Packer, A., and Clay, K. 2000. Soil pathogens and spatial patterns of seedling mortality in a temperate tree. Nature, 404: 278-281.

Packer, A., and Clay, K. 2003. Soil pathogens and Prunus serotina seedling and sapling growth near conspecific trees. Ecology, 84: 108-119.

Pastor, J., Aber, J.D., and McClaugherty, C.A. 1984. Aboveground production and N and P cycling along a nitrogen mineralization gradient on Blackhawk Island, Wisconsin. Ecology, 65: 256-268.

Reinhart, K.O., Packer, A., Van der Putten, W.H., and Clay, K. 2003. Plant-soil biota interactions 
Contrasting effects of seed pathogens...

and spatial distribution of black cherry in its native and invasive ranges. Ecol. Lett. 6: 10461050.

Reinhart, K.O., and Callaway, R.M. 2004. Soil biota facilitate exotic Acer invasions in Europe and North America. Ecol. Appl. 14: 1737-1745.

Reinhart, K.O., Royo, A.A., Van der Putten, W.H., and Clay, K. 2005. Soil feedback and pathogen activity in Prunus serotina throughout its native range. J. Ecol. 93: 890-898.

Schafer, M., and Kotanen, P.M. 2003. The influence of soil moisture on losses of buried seeds to fungi. Acta Oecologica 24: 255-263.

Schopmeyer, C.S. (ed.) 1974. Seeds of woody plants in the United States. Agriculture Handbook No. 450. U.S. Dept. of Agriculture, Forest Service, Washington D.C.

Seiwa, K. 1998. Advantages of early germination for growth and survival of seedlings of Acer mono under different overstory phenologies in deciduous broad-leaved forests. J. Ecol. 86: 219-228.

Sharvelle, E.G. 1961. The nature and uses of modern fungicides. Burgess Publishing, Minneapolis.

Stanosz, G.R. 1993. Benomyl and acephate applications increase survival of sugar maple seedlings during their first growing season in northern Pennsylvania. Can. J. For. Res. 24: 1107-1111.

Tomita, M., Hirubuki, Y., and Seiwa, K. 2002. Post-dispersal changes in the spatial distribution of Fagus crenata seeds. Ecology 83: 1560-1565.

Torgeson, D.C. (ed.) 1969. Fungicides: an advanced treatise, volume II: chemistry and physiology. Academic Press, New York.

Van der Putten, W.H. 2003. Plant defence below ground and spatio-temporal processes in natural vegetation. Ecology 84: 2269-2280. 
Van der Putten, W.H., Van Dijk, C., and Peters, B.A.M. 1993. Plant-specific soil-borne diseases contribute to succession in foredune vegetation. Nature 362: 53-56.

Van Mourik, T.A., Stomph, T.J., and Murdoch, A.J. 2005. Why high seed densities within buried mesh bags may overestimate depletion rates of soil seed banks. J. Appl. Ecol. 42: 299-305.

Wardle, D.A. 2002. Communities and ecosystems: linking the above-ground and below-ground components. Princeton University Press, Princeton.

Weber, A., Karst, J., Gilbert, B., and Kimmins, J.P. 2005. Thuja plicata exclusion in ectomycorrhiza-dominated forests: testing the role of inoculum potential of arbuscular mycorrhizal fungi. Oecologia 143: 148-156.

Wenny, D.G., and Levey, D.J. 1998. Directed seed dispersal by bellbirds in a tropical cloud forest. Proc. Nat. Acad. Sci. U.S. 95: 6204-6207.

Wills, C., Condit, R., Foster, R.B., and Hubbell, S.P. 1997. Strong density- and diversity-related effects help to maintain tree species diversity in a neotropical forest. Proc. Nat. Acad. Sci. U.S. 94: $1252-1257$.

Wright, S.J. 2002. Plant diversity in tropical forests: a review of mechanisms of species coexistence. Oecologia 130: 1-14.

Zhong, J., and van der Kamp, B. 1999. Pathology of conifer seed and timing of germination in high-elevation subalpine fir and Englemann spruce forests of the southern interior of British Columbia. Can. J. For. Res. 29: 187-193. 
Table 1. Results of ANOVAs (blocked by site) of the estimated proportion of Acer saccharum and Tsuga canadensis seeds which survived the experiment; see Figure 1 for treatment means.

\begin{tabular}{lccccccccc}
\hline & \multicolumn{7}{c}{ Acer saccharum } & \multicolumn{5}{c}{ Tsuga canadensis } \\
Factor & MS & $\mathrm{df}^{\mathrm{c}}$ & $\mathrm{F}^{\mathrm{d}}$ & $\mathrm{p}$ & $\mathrm{MS}$ & $\mathrm{df}^{\mathrm{c}}$ & $\mathrm{F}^{\mathrm{d}}$ & $\mathrm{p}$ \\
& & & & & & & & & \\
\hline Habitat $^{\mathrm{a}}$ & 0.036 & 1 & 0.323 & 0.579 & 0.007 & 1 & 0.024 & 0.880 \\
Site(Habitat) & 0.110 & 13 & 0.857 & 0.609 & 0.313 & 14 & 1.705 & 0.180 \\
Treatment $^{\mathrm{b}}$ & 0.532 & 1 & 4.124 & 0.067 & 0.190 & 1 & 1.033 & 0.330 \\
Habitat x Treatment & 0.000 & 1 & 0.002 & 0.968 & 1.077 & 1 & 5.867 & 0.032 \\
Residual & 0.129 & 11 & & & 0.184 & 12 & & \\
\hline
\end{tabular}

a Type of site where seeds were buried (A. saccharum vs. T. canadensis stands)

b Seeds protected with fungicide vs. controls

${ }^{\mathrm{c}}$ Degrees of freedom vary slightly as a consequence of missing data

d Tests of "Habitat" are based on a synthesized denominator MS with Satterthwaite's degrees of freedom: A. saccharum MS $=0.111, \mathrm{df}=13.9 ;$. canadensis $\mathrm{MS}=0.305, \mathrm{df}=15.0$ 
Contrasting effects of seed pathogens...

\section{Figure Captions}

Figure 1. Estimated proportion of seeds which survived the experiment. "Proportion surviving" includes both germinated seeds and ungerminated but apparently viable seeds. Seeds of (a) Acer saccharum and (b) Tsuga canadensis buried in two habitat types (A. saccharum vs. T. canadensis stands) were subjected to two experimental treatments (fungicide or control). Shown are means + standard errors; "n" indicates sample size. Sample sizes vary slightly because seed bags that were not recovered intact were excluded from the analyses. See Table 1 for results of significance tests. 


\section{Figure 1}

(a)

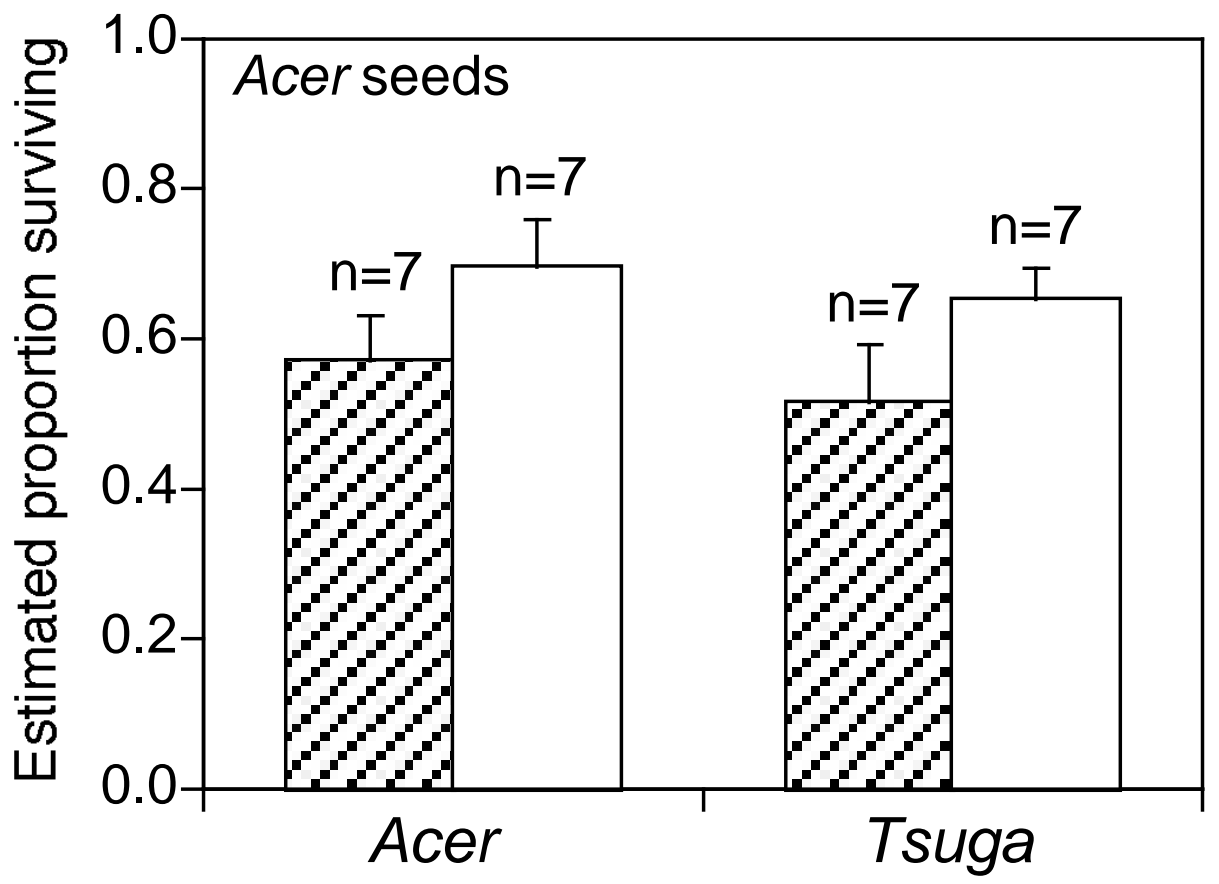

(b)

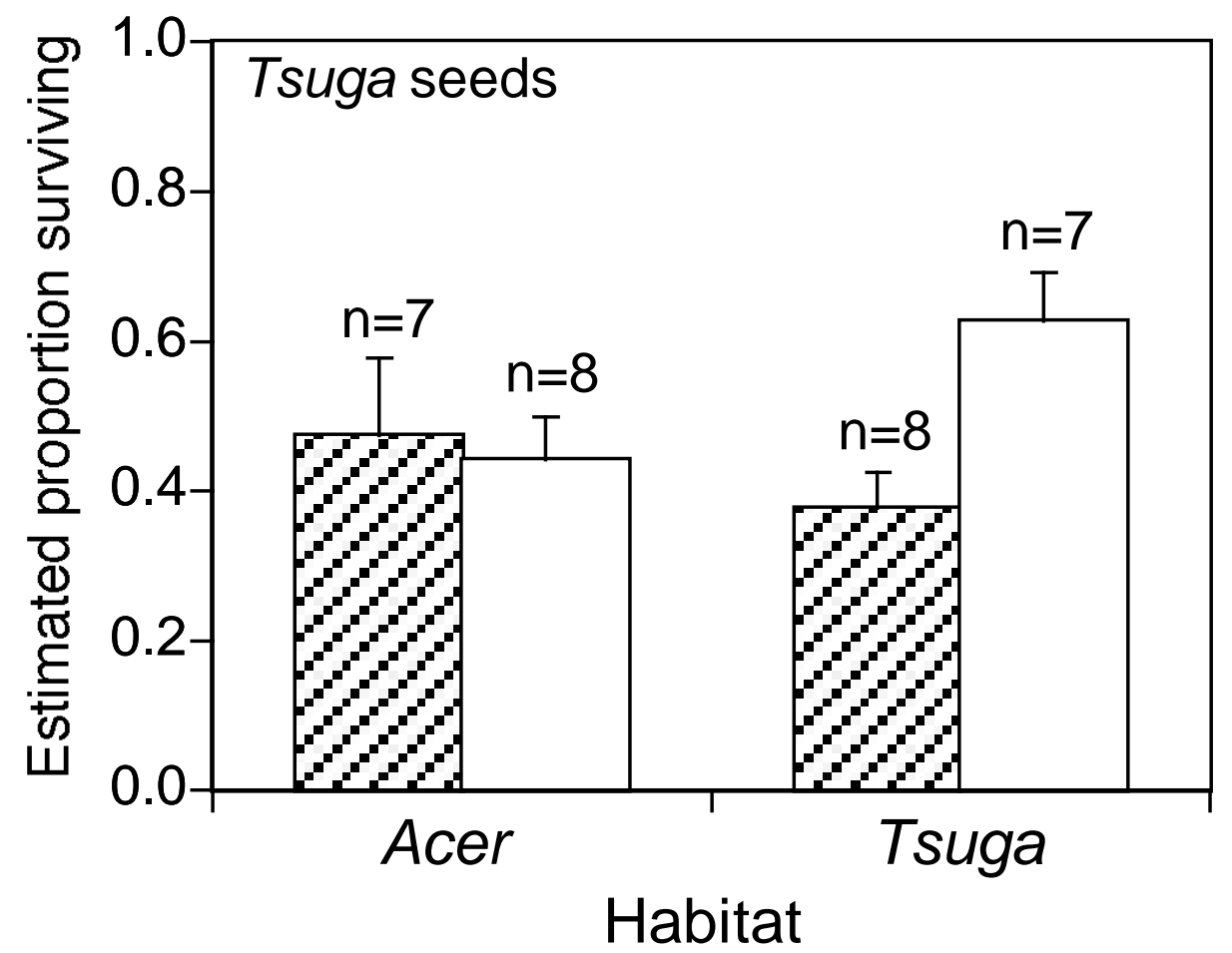

$Q$ Control

Fungicide 